\title{
Talent Agents and the Implications of Actor Placement
}

Constructing Artists' Value Through Television Drama

Les agentes artistiques et les enjeux du placement des comédien'ne·s. Construire la valeur des artistes par les fictions télévisées

Los agentes artísticos y los desafíos de emplear a actores y actrices. Construir el valor de los artistas y ponernos a trabajar en las ficciones televisivas

\section{Delphine Naudier}

Translator. Daniela Ginsburg

\section{(2) OpenEdition}

\section{Journals}

Electronic version

URL: http://journals.openedition.org/bssg/428

DOI: $10.4000 /$ bssg. 428

ISSN: 2490-9424

Publisher

Presses universitaires de Vincennes

\section{Electronic reference}

Delphine Naudier, "Talent Agents and the Implications of Actor Placement", Biens Symboliques / Symbolic Goods [Online], 6 | 2020, Online since 30 April 2020, connection on 04 March 2021. URL: http://journals.openedition.org/bssg/428 ; DOI: https://doi.org/10.4000/bssg.428 


\section{Les agentes artistiques et les enjeux du placement des comédien'ne's}

\section{Construire la valeur des artistes par les fictions télévisées}

Talent Agents and the Implications of Actor Placement

Constructing Artists' Value Through Television Drama

\author{
Delphine Naudier \\ traduction | translation \\ Daniela Ginsburg
}

\begin{abstract}
Depuis les années 1990, nombre de travaux sur les productions de fictions audiovisuelles se sont intéressés à différentes activités telles que scénariste (Pasquier 1995 ; Chalvon-Demersay \& Pasquier 1993), technicien (Le Guern 2006) ou producteur de télévision (Brigaud-Robert 2011), attestant combien la chaîne de coopération (Becker 1988) qui structure ces activités de production collective fait l'objet de fortes tensions entre les contraintes artistiques et économiques, d'une part, et les rapports de pouvoir pour défendre l'autonomie et la légitimité de chaque territoire professionnel, d'autre part (Pasquier 2008). Si les travaux français récents sur les séries télévisées ont analysé le processus de division et de hiérarchisation du travail à l'œuvre dans l'organisation de la production (Mille 2013, 2016), et mis en évidence l'émergence de nouvelles figures dans cette segmentation des territoires professionnels, comme les showrunners (Esquenazi 2010), en France ${ }^{1}$, pourtant, aucune
\end{abstract}

1. Pour les États-Unis, sur ce sujet, voir notamment Bielby \& Bielby (1993, 1999).
Since the 1990s, research on audio-visual works of fiction has focused on various activities, including the work of television screenwriters (Pasquier 1995 ; Chalvon-Demersay \& Pasquier 1993), technicians (Le Guern 2006), and producers (BrigaudRobert 2011), demonstrating to what extent the chain of cooperation (Becker 1982) that structures these collective activities of production is affected by major tensions between artistic and economic constraints on the one hand, and power relations as each professional territory attempts to defend its autonomy and legitimacy on the other hand (Pasquier 2008). While recent works in France on television series have analysed divisions and hierarchies of labour in the organization of productions (Mille 2013, 2016) and have explored the emergence of new figures such as showrunners (Esquenazi 2010) within the segmentation of professional territories ${ }^{1}$, in France, no study has yet looked at how

1. On the United States, see, among other references, Bielby \& Bielby 1993; 1999. 
enquête n'a appréhendé la contribution des agentes ${ }^{2}$ artistiques au placement des artistes dans ces programmes de télévision. Tel est l'objet de cet article. talent agents contribute to the placement of artists on television programmes. This will be the focus of the present article.

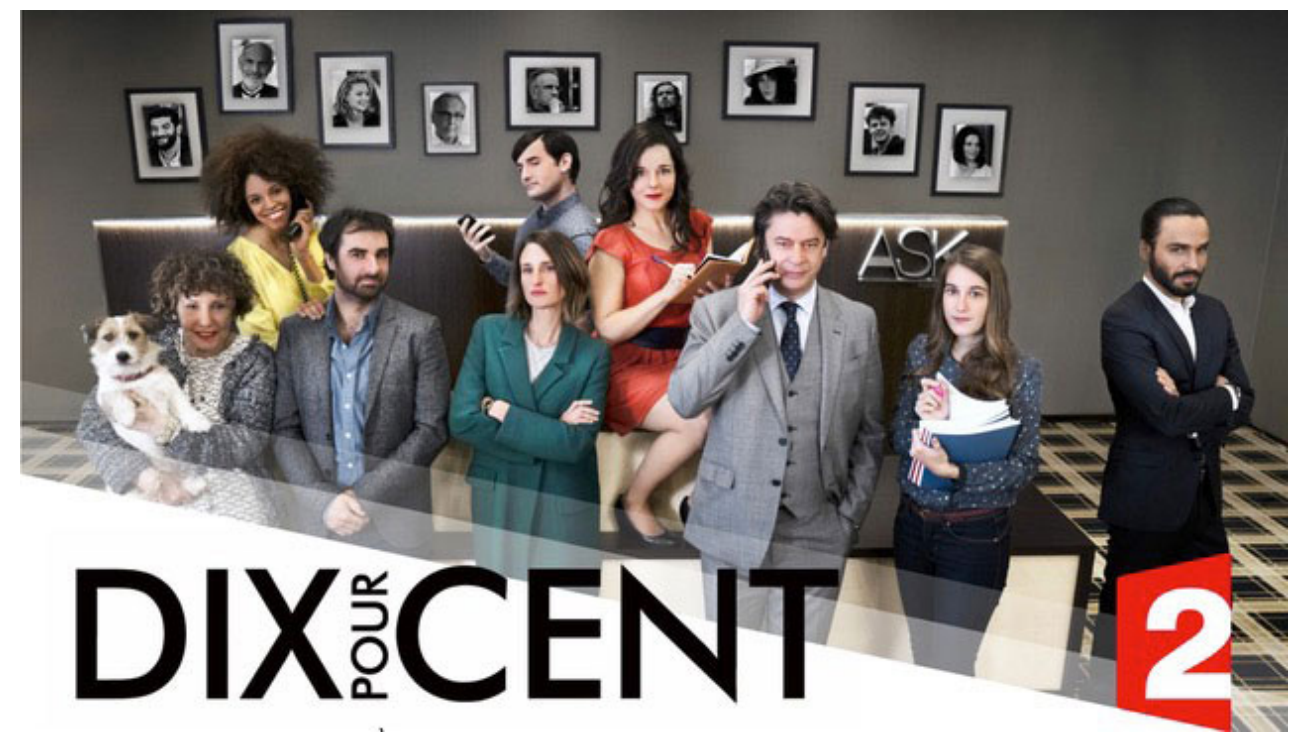

Fig. 1. Promotion pour la saison 2 de la série Dix pour cent (avril 2017) / Advertisement for Season 2 of the French Series "Call My Agent" (April 2017) @ Les Dessous de scène

Les agentes artistiques représentent les intérêts de leur clientèle artistique, négocient en leur nom projets et rémunérations, et participent à leur mise au travail. Elles sont commissionnées à hauteur de $10 \%{ }^{3}$ pour toutes les formes de rémunération négociées

2. Ce groupe professionnel étant aux trois quarts composé de femmes, qu'elles soient agentes ou assistantes d'agentes, nous avons opté pour l'usage du féminin universel. Nous utiliserons le genre d'état civil dès lors que nous citerons les propos anonymisés des enquêté $e \cdot s$.

3. D'où le titre de la série Dix pour cent, diffusée par France 2, qui a permis de sortir l'activité des agentes de l'ombre où elle se trouvait depuis longtemps
Talent agents represent the interests of their artist clients, negotiate their projects and remuneration, and participate in finding them work. They are paid a ten per cent ${ }^{2}$ commission on all the wages and other forms of compensation they negotiate for their clients (Lizé, Naudier, Roueff 2011). Thus, their work consists in showcasing their clients' symbolic and commercial value (Naudier 2015 ; Roussel

2. Whence the title of the French show Dix pour cent ("Ten per cent"; English title "Call My Agent!") broadcast by the French public service TV network France 2. This show, created in 2015, has cast light on the work done by agents, which had long remained in the shadows (Naudier 2014). 
pour leur clientèle (Lizé, Naudier, Roueff 2011). Leur activité consiste ainsi à réaliser un travail de mise en valeur symbolique et commerciale de leur clientèle (Naudier 2015 ; Roussel 2017) dans un cadre professionnel d'intermittence où s'enchevêtrent non seulement des temporalités différentes (le temps court des projets lié à l'offre conjoncturelle des emplois, aux nécessités matérielles ou symboliques de s'y investir, et le temps long de la carrière qui prend forme) mais aussi des possibilités de réalisation incertaines qui indexent la carrière aux projets, et les projets à la carrière

(Pilmis \& Cardon $2013: 45$ ).

Les placements concernent principalement trois domaines : la télévision, le cinéma et le théâtre. Si le théâtre conserve son statut d'art noble, le cinéma est cependant l'objectif privilégié pour la plupart des artistes, quand la télévision, elle, attire les projets les plus nombreux. Selon nombre de témoignages convergents, le cinéma est le secteur où les cachets sont les plus rémunérateurs, ensuite vient la télévision, puis le théâtre considéré comme le « parent pauvre »(Entretien, agent, 2013). II s'agit dès lors d'appréhender l'enjeu que constitue le placement au sein de l'espace de production télévisuel, dans un contexte d'“ anoblissement " des séries (Glevarec 2012) et de consensus discursif - tant du côté des artistes, de la presse journalistique spécialisée que des politiques publiques qui, souvent affirment que les frontières entre séries télévisées et cinéma s'estompent en raison de la montée en qualité des programmes télévisuels (McCabe \& Akass 2007). La fluidité de circulation entre les espaces de production serait ainsi réalisée, et les différences hiérarchiques entre télévision et cinéma s'en verraient réduites, signe d'une " hétérogénéité des ordres de légitimité culturelle »(Glévarec 2005). Pour mettre à l'épreuve ces assertions, il faut d'abord saisir quels mécanismes

(Naudier 2014)
2017) within a professional context defined by intermittence, whereby different temporalities (the short term nature of projects, where job offers depend on the economic context of the moment, and on the material or symbolic factors that make it necessary to invest in them; and the long-term temporality of a career as it takes shape) are entangled with uncertain production possibilities that link a career to projects and projects to a career (Pilmis \& Cardon 2013: 45).

Actors are mainly placed in projects within three domains: television, cinema, and theatre. While theatre is still seen as a noble art, cinema is the goal for most artists, whereas television generates the most projects. According to a number of converging statements, cinema is the sector that pays the best, followed by television and then finally theatre, considered a "poor relation" (Interview, agent, 2013). We must thus consider what is at stake in the process of placing actors in television productions within the context of the "ennoblement" of television series (Glevarec 2012) and of the discursive consensus, expressed by artists, by entertainment media, as well as by public policies, according to whom the boundaries between television series and movies have become blurred as a result of the increased quality of television programmes (McCabe \& Akass 2007). It is said that circulation between these spaces of production has become fluid, and the hierarchical differences between television and cinema reduced, indicating a "heterogeneity of orders of cultural legitimacy" (Glévarec 2005). To test these claims, we must first examine the mechanisms of valorization agents use to construct and justify their actor placements. Next, we must analyse the implications and professional practices surrounding these placements from the point of view of agents. Finally, I will show how, since the 2010s, 
de valorisation sont activés par les agentes pour construire et justifier les raisons de ces placements. On analysera ensuite les enjeux et usages professionnels de ces placements du point de vue des agentes. Enfin, on examinera comment, depuis les années 2010, la concurrence des comédien·ne·s de cinéma redistribue les profits symboliques et matériels sur le marché de l'emploi des séries, pris en tension entre crainte de déclassement et bénéfice

de reclassement.

\section{Méthodologie}

Cette enquête se fonde sur plus de cent cinquante entretiens semi-directifs réalisés, en France, avec des agentes et assistant·e.s d'agentes artistiques, des cinéastes, des scénaristes, des comédien.ne-s, des responsables de distribution artistique, des producteur.rice-s et des avocat·e.s. Les entretiens portaient sur les trajectoires professionnelles et les pratiques de l'activité de placement et de négociation des emplois dans les différents secteurs. Des observations ont été réalisées dans trois agences parisiennes de taille et de réputation contrastées. Si les observations ont été de courte durée (environ une semaine en continu chacune), en raison des résistances à toute présence prolongée, en revanche les nombreux entretiens, de plusieurs heures, parfois répétés sur plusieurs années, ont nourri cette enquête d'observations ethnographiques. En effet, les entretiens se déroulant généralement sur le lieu de travail, nombre de transactions, effectuées principalement par téléphone ou par mail, ont été réalisées sous mes yeux, et commentées à ma demande. Les agentes continuaient généralement leur activité pendant l'entretien, qui était souvent interrompu par les assistant·e.s et les appels téléphoniques, voire par la venue impromptue de client·e·s. Les entretiens ont été complétés par la consultation des récits d'artistes sur leurs relations aux agentes ou sur leur métier, publiés dans la presse écrite ou audiovisuelle. Enfin, cette recherche s'inscrit en prolongement d'une enquête de sociologie historique des agents artistiques (Naudier 2018a). competition from movie actors has redistributed symbolic and material profits across the job market for television series, which is dominated by the tension between fears of downclassing and the benefit of upclassing.

\section{Methodology}

This study is based on more than 150 semi-structured interviews carried out in France with talent agents, their assistants, directors, screenwriters, actors, heads of casting agencies, producers, and lawyers. The interviews focused on professional trajectories, placement practices, and employment negotiations in the various sectors. I also observed three Parisian agencies of different sizes and reputations. Although these observations were short term (about a week at each agency) because of resistance to any prolonged outsider presence, they were bolstered by many interviews conducted at the work site. These lasted several hours each, and some were repeated over the course of several years, thus providing the study with ethnographical details. In fact, a number of transactions were made in my presence, principally by telephone or email, and commented, at my request, by the respondents. In general, agents continued to work during our interviews, which were often interrupted by assistants, the telephone, or impromptu visits from clients. These interviews were supplemented by artists accounts of their relations to agents and to their profession, published in the written press or made during radio or TV interviews. This research continues my work on the historical sociology of talent agents (Naudier 2018a). 


\section{Construire la légitimité professionnelle dans les fictions télévisuelles}

Face à l'hétérogénéité et à la multiplicité des programmes et des interlocuteurs intervenant dans les différentes chaînes de télévision (responsables de direction artistiques, programmateurs de télévision, sociétés de production indépendantes et publiques de fictions télévisées), la présence d'agentes artistiques s'est imposée sur ce marché des emplois en France, comme dans nombre de pays occidentaux. La position incontournable des agentes est manifeste puisque, déjà en 1994, les deux tiers des comédien·ne.s de télévision ont un·e agent·e, et cette pratique distingue plus encore les moins de trente ans des plus de cinquante ans (Menger 1997a). Parallèlement, le nombre de comédien·ne.s a été multiplié par quatre depuis les années 1980 pour s'élever à plus de 30000 dans les années 2010. L'intervention des agentes consiste à faire valoir les intérêts de chacun·e de leurs client·e.s auprès des employeurs et financeurs avec qui elles entretiennent des liens d'interconnaissance. Le « travail de réputation » des agences (Zafirau 2008) se construit en lien avec la mise en visibilité des $\mathrm{CV}$ en ligne de leur clientèle figurant sur le site des agences - un procédé qui permet de construire l'identification nominale attachée à un physique par rapport aux autres professionnel·le·s

sur le marché.

Faire le « nom » des artistes dans cette «économie des singularités » (Karpik 2007) repose sur la « combinaison innovante de plusieurs principes d'évaluation ou registres d'action » (Bessy \& Chauvin 2014) à faire valoir dans une « configuration d'intermédiation » (Naudier 2018a). Dès lors, le travail de placement et son corollaire, la fabrique de la valeur d'échange, reposent sur plusieurs mécanismes de valorisation visant à produire et à diffuser des « conventions de qualité » (Bessy \& Eymard-Duvernay 1997) en

\section{Constructing Professional Legitimacy in TV Drama}

Given the heterogeneity and multiplicity of television programmes and of the interlocutors involved in television networks (artistic directors, television programmers, independent and public production companies), talent agents became a necessary presence in the television job market in France, as in many other Western countries. The indispensability of agents is obvious: in 1994, two-thirds of television actors already had agents, and having an agent is even more common among television actors under 30 than among those over 50 (Menger 1997a). Moreover, the number of actors has increased fourfold since the 1980s, reaching 30,000 during the 2010s. The agent's role is to represent her ${ }^{3}$ clients' interests to employers and financers, with whom she maintains relationships of acquaintance. Agencies' "reputation work" (Zafirau 2008) involves making their clients' CVs visible on the agency website, a process that allows them to build name recognition in connection with a physique, and to thus distinguish actors and actresses from their rivals.

Making "a name" for an artist within this "economy of singularities" (Karpik 2011) depends on an "innovative combination of several principles of evaluation or registers of action" (Bessy \& Chauvin 2014) within a "configuration of intermediation" (Naudier 2018a). Thus, the work of placement and its corollary, the creation of exchange value, are based on various mechanisms of valorization

3. This professional group is dominated by women, who make up seventy-five per cent of agents and agent assistants. 
certifiant la valeur de la clientèle. En l'espèce, un projet artistique est « à la fois un travail, un emploi et un produit » (Cardon \& Pilmis 2013 : 46) dont chacune des dimensions est appréhendée selon

une grille de perception de la qualité.

La qualité attachée à chacune de ces dimensions oppose les programmes de fiction dits de " prestige » à d'autres considérés comme "bas de gamme ", même si certaines fictions considérées de moindre valeur s'avèrent, grâce à leur longévité, être de bons placements. Se dessine au gré des entretiens un discours, également diffusé dans les médias, selon lequel la dualité des programmes s'exprime par l'évolution, en France, d'une « télé en train de se moderniser [avec des séries] de grande qualité, [...] super bien écrit[es], super bien tenu[es] » qui se substituerait à une « télé populaire, un peu traditionnelle et un peu vieillotte "

(Entretien, agente, 2018)

Si les droits d'entrée dans l'espace des productions télévisuelles sont plus faibles qu'au cinéma, l'impératif de l'audience, quel que soit le rôle dans la distribution, est le critère majeur de décision pour le maintien ou l'éviction d'un programme. Dans ce contexte, trois mécanismes de valorisation sont à l'œuvre pour intégrer l'espace télévisuel : le premier est fondé sur l'audience, le deuxième sur la constitution d'un capital spécifique télévisuel, et le troisième sur la constitution d'un capital reconvertible dans

l'espace cinématographique.

\subsection{La légitimité par l'audience}

Dans l'espace des productions télévisées, le turn-over des emplois est important, en raison de l'impératif de pourvoir les programmes en nouveaux visages. Les droits d'entrée étant peu élevés, les that seek to produce and spread "conventions of quality" (Bessy \& Eymard-Duvernay 1997) by certifying the value of their clients. Here, an artistic project is "a profession, a job, and a product at the same time" (Cardon \& Pilmis 2013: 46), each aspect of which is apprehended through the lens of quality.

The perceived level of quality sets "prestige" programmes apart from those considered "low-end"-although, if it has a long enough run, a show considered to be of lesser value can still be a good placement for actors. Over the course of my interviews, a discourse emerged that can also be found in the media: in France, there is a "television that is in the process of modernizing itself, [with] high quality, super well written, super well done series," and it is in the process of replacing a television, which was "mainstream, somewhat traditional and somewhat old-fashioned" (Interview, agent, 2018).

While it is easier to access the space of television production than the space of movies, audience response-whatever the role in the cast-is the major criterion for deciding whether to maintain or cancel a programme. In this context, three mechanisms of valorization are at work when an actor or actress enters the space of television: the first is based on the audience, the second on the constitution of a capital specific to television, and the third on the creation of a capital that can be converted in the space of cinema.

\subsection{Legitimacy Through the Audience}

Within the space of television productions, there is high job turnover as a result of the constant need to fill programmes with new faces. Therefore, the cost of entry to this space being rather low, agents 
agentes, dès lors, y placent leur clientèle, notamment les plus jeunes artistes, puisque l'audience des chaînes est un accélérateur de la notoriété

«Au cinéma, pour se faire connaître, il faut faire un film qui fait des millions d'entrées ou un petit film mais que toute la presse salue. Mais ce n'est pas gagné qu'après un rôle principal au cinéma, on soit connu. Loin de là. Disons que, c'est vrai qu'après une série comme ça ${ }^{4}$, ce sont quand même trois ou quatre millions de personnes à chaque épisode qui l'ont vue : donc c'est une petite notoriété, quoi. » (Agente, entretien, $2^{\mathrm{e}}$ sur 3

2013.)

Toutefois, malgré les possibilités de faire connaître les artistes, le critère d'audience, comme instance de jugement majeur, s'avère à double tranchant. Dans les stratégies économiques de programmation, la logique du casting, consistant à « produire l'évidence » (Cardon 2016) entre l'artiste et le personnage, trouve là sa limite. Ce critère d'audience $a$, en effet, son revers : celui de faire primer le produit (le programme) sur l'emploi d'un.e comédien·ne :

“Moi j'ai récupéré $X X$ qui était récurrent sur [série télévisée] : ils [la chaîne et les producteurs] l'ont jeté comme un vrai malpropre. [...]. II n'y avait pas assez d'audimat donc ils ont décidé qu'ils allaient changer et qu'ils allaient prendre une femme à la place. [...] Ils l'ont jeté comme une vieille chaussette et plus personne n'en veut sur TF $1^{5}$. Dès qu'on le propose pour d'autres séries, ils n'en veulent pas. Et je ne sais pas ce que je peux faire avec les autres chaînes. [...] Donc là, tout d'un coup, c'est le creux alors qu'il a bien travaillé pendant longtemps. Parce que quelqu'un a décidé de le jeter, plus personne n'en veut » (Agente, entretien,

4. L'agente évoque une série sur France Télévision dans laquelle son client incarne le rôle principal.

5. TF1 est la première chaîne de télévision privée en France. tend to place their clients-especially the youngest ones-on television shows, since network audiences act as accelerators of fame:

"In the movies, in order to become well known, you have to do either a film that sells millions of tickets, or else a small film that all the critics love. There's no guarantee that after starring in a movie you'll be well known. Far from it. But after a series like that ${ }^{4}, 3$ or 4 million people will have seen you in each episode, so yeah, that's a bit of fame." (Agent, Interview, 2nd of 3, 2013.)

Nevertheless, although audience response allows artists to become well known, using the audience to make major judgments turns out to be a double-edged sword. Within the economic strategies of programming, the logic of casting, which consists in creating an obvious connection between an artist and a character, reaches its limit. The flip side of the audience response criterion is that the product (the programme) becomes more important than an actor's job:

"I picked up XX who had a recurring role on [television series]: they [the network and the producers] threw him out like he was trash... They weren't getting high enough ratings, so they decided to make a change and hire a woman instead of him... And they threw him away like a dirty old sock and now no one wants him on TF1 ${ }^{5}$. Now when we propose him for other series, they don't want him. And I don't know what I'll be able to do as far as the other networks... So now all of a sudden he's not working, although he worked a lot for a long time. Because one day someone decided to kick him out,

4. The agent is referring to a series on the French public service television in which her client played the lead role.

5. TF1 is the leading private television network in France, it was created in 1975. 
2013).

L'importance des critères financiers accroît ainsi les risques de fermeture des emplois avec lesquels les agentes doivent composer pour « vendre » plus ou moins aisément les artistes d'un projet à l'autre. Outre l'audience et le format se cumulent d'autres critères de qualité. Leur hiérarchie varie, par exemple, selon l'heure de diffusion (la première partie de soirée étant le créneau horaire le plus prisé car le plus regardé). En effet, les chaînes investissent des moyens inégaux selon l'horaire et les publics ciblés. Du point de vue des agentes, réduire l'incertitude sur les emplois futurs consiste, dans cette économie du pari, à anticiper le placement d'un·e comédien·ne, quitte parfois à brader quelque peu son cachet avec son consentement :

« J'ai vu les premières images, il va y avoir un buzz là-dessus, donc voilà : si ça marche, ça va m'apporter d'autres choses [...]. Je sais très bien qu'il va y avoir un peu de presse autour ! [...] C'est un unitaire [un film pour la télévision] "prestige" TF1 avec un réalisateur de long métrage, deux stars [...] avec des gens de cinéma : ça va être une soirée "prestige". Je sais très bien qu'elle ne passera pas inaperçue, que ce sera une belle soirée, qu'elle sera sûrement présentée à La Rochelle ${ }^{6}$, je sais très bien que ça va être en lumière. [...] II faut qu'on y aille, on ne peut pas ne pas aller dans ce genre de produit !» (Agente, entretien, 2013.)

La grandeur par côtoiement, réalisée par des appariements théoriquement efficients, en cumulant les signes de qualité (cinéaste, stars, second rôle, festival, presse, unitaire «prestige », TF1,

6. Le Festival de la fiction TV de La Rochelle est consacré à la promotion des œuvres de fiction télévisuelles francophones et internationales. II a été créé en 1999 à Saint-Tropez et se tient en septembre chaque année à La Rochelle depuis 2007. II remet une quinzaine de prix par année. now no one wants him anymore." (Agent, Interview, 2013.) Thus, the importance of financial criteria increases the risk that a job might end; agents must factor in this risk as they "sell" artists from one project to another with more or less ease. There are other criteria of quality in addition to audience size and format: for instance, there is a hierarchy of broadcast times (the early evening being the most coveted time slot because it has the most viewers) Indeed, networks invest different amounts in shows depending on their broadcast time and target audience. From the point of view of agents, within this economy based on making bets, reducing the uncertainty surrounding future jobs consists in anticipating an actor's placement, even if it means lowering his or her fee, if he or she agrees:

"I saw the first images, there's going to be a buzz about it, so if it goes well, it will bring me other things... I know very well there's going to be some press around this! [...] It's a prestige piece from TF1 directed by a film director, with two stars [...] with movie people so it's going to be a prestige evening. I know perfectly well it won't go unnoticed, and that it's going to be a great night and it's certainly going to be presented at La Rochelle ${ }^{6}$, that it's going to get attention. [...] We have to go, you can't not go when it's this kind of product." (Agent, Interview, 2013.)

Greatness by association, achieved through theoretically efficient pairings and by accumulating markings of quality (filmmakers, stars, supporting roles, festivals, press, "prestige" pieces, etc.) is

6. The television drama Festival in La Rochelle is dedicated to promoting French and international works of television drama. It was created in 1999 in Saint-Tropez and has been held each September in La Rochelle since 2007; some fifteen prizes are awarded there each year. 
etc.), participe de cette mise en valeur du nom des comédien.ne.s suspendue à la réception incertaine $d u$ « produit ». Faire avec les aléas des offres d'emploi conduit à opter pour des stratégies visant à assurer une rentabilité à moyen terme, en construisant un capital médiatique propre à la télévision.

\subsection{Une mobilité de chaîne : comédien de télévision}

Les agentes doivent s'ajuster et composer avec les caractéristiques des chaînes, qui sont le premier critère pris en compte. Que ce soit une chaîne réputée pour ses audiences, comme TF1, ou marquée par une image " cinéma » comme Canal $+^{7}$ ou $\mathrm{Arte}^{8}$, ou encore entourée de l'aura de " qualité » des chaînes de service public, la valorisation des artistes se fera en fonction de critères distinctifs selon chacune des chaînes. Le capital médiatique se traduit par trois modalités permettant une plus ou moins grande amplitude de la carrière, que l'on qualifiera de mobilité de chaîne. Cette dernière est fortement liée au rang acquis dans les distributions selon le statut des emplois (récurrent, semi-récurrent ou guest). Elle se déploie dans l'espace télévisuel où le capital médiatique, lié à l'identification du nom grâce aux scores d'audience, peut être monnayé par les agentes.

Les récurrent·e.s sont employé·e.s pour « tenir » une série et la «porter » sur leurs épaules. Cette place de premier plan est un atout, mais à condition, selon plusieurs agentes, d'en « partir à temps ». Ces rôles médiatiques procurent des bénéfices symboliques, voire garantissent des promotions professionnelles en accédant, par

7. Première chaîne de télévision à péage créée en France en 1984, elle est historiquement spécialisée dans les programmes sportifs et de cinéma. Elle produit et diffuse de nombreuses séries.

8. Chaîne de télévision publique franco-allemande créée en 1992, elle a une vocation culturelle européenne. part of showcasing an actor's name, which hangs on the uncertain reception of the "product." Dealing with the vagaries of job offers leads to choosing strategies that ensure profitability in the medium term, by building media capital specific to television.

\subsection{Network Mobility: Television Actors}

Agents must adapt to and work with the characteristics of networks - the first criteria they take into account in considering television placements for their clients. Whether they are dealing with a network known for its audiences, such as, in France, TF1, or for its cinematic reputation, such as Canal ${ }^{7}$ or $\mathrm{Arte}^{8}$, or for having an aura of "quality," such as the public broadcast networks, the valorization of artists is achieved on the basis of distinctive criteria specific to each network. Media capital is expressed in three modalities that allow for a wider-ranging or narrower career-what I will call network mobility. This mobility is tightly linked to whether an actor is cast in a regular role, a recurring role, or as a guest star. It exists within a televisual space where media capital, linked to name recognition through audience ratings, can be mediated by agents.

Series regulars are hired to "hold down" a show and to "carry it" on their shoulders. Landing such a prominent role is a plus, but, according to several agents, only if the actor "gets out in time." These roles procure symbolic benefits and can even guarantee professional advancement by leading, for example, to production

7. Canal+ was the first pay-TV network in France, created in 1984; historically it has specialized in sports and film. It produces and distributes numerous series.

8. Arte is a public French-German television network created in 1992 with a focus on European culture. 
exemple, à des parts de production, ou en scénarisant et réalisant certains épisodes. L'image du héros ou de l'héroïne à l'emploi du temps rempli de jours de tournage pour une série est la rançon de la gloire télévisuelle. L'arbitrage se joue alors en négociant le fait d'être « à l'abri du besoin en faisant quelques réserves » sans “ s'enfermer dans un rôle » (Entretien, agente, 2013). L'empreinte d'un programme phare, comme certaines séries policières ou familiales, ferme l'accès à de nombreux emplois, notamment quand l'identité " du Héros de Série Télévisée » (Chalvon-Demersay, 2011) en vient à se substituer au nom de l'artiste : Roger Hanin devenant « Navarro ${ }^{9}$ », Mimie Mathy « Joséphine Ange Gardien ${ }^{10}$ » ou Véronique Genest « Julie Lescaut ${ }^{11}$ ». La carrière peut alors être limitée aux emplois de la chaîne, comme l'indique ce comédien :

"Si vous êtes vraiment star de TF1, vous n'allez pas travailler avec la 2 [France $2^{12}$ ] ou, plutôt, si vous êtes une star de la 2, TF1 ne voudra pas de vous. » (Entretien, comédien, 2012.)

La concurrence entre les chaînes se réfracte à l'échelle des carrières artistiques. Nombre de ces comédien.ne·s interviennent dès lors comme guest avec un rôle de moindre ampleur dans un unitaire ou d'autres séries de la chaîne. Le nom de l'artiste est alors suivi de sa mention au générique de début « avec la participation exceptionnelle de » pour le distinguer du reste de la distribution

9. Série policière française diffusée sur TF1 entre 1989 et 2007 dont le rôletitre, l'inspecteur Navarro, était incarné par l'acteur Roger Hanin.

10. Série de comédie dramatique française diffusée sur TF1 depuis 1997. Mimie Mathy est une humoriste, devenue actrice principale et co-productrice de la série, voir Joséphine Ange Gardien.

11. Série policière française diffusée sur TF1 entre 1992 et 2014, Véronique Genest était alors l'une des premières actrices à incarner une femme commissaire de police à l'écran. Voir Julie Lescaut.

12. France 2 est la première chaîne publique en France. credits, or to the opportunity for an actor to write or direct certain episodes. The image of the hero or heroine whose schedule is filled with days spent filming a series is the price of television glory. Brokerage means negotiating so that an actor is "sheltered from need while also building up reserves" but without "being locked in a role" (Interview, agent, 2013). The imprint of a flagship show, such as certain detective or family shows, closes the door to many jobs, in particular when an actor's identity as a "TV Series Hero" (Chalvon-Demersay 2011) replaces his or her name: for example, among the most popular shows of French television in the 1990s and early 2000s, Roger Hanin has become "Navarro9", Mimie Mathy has become "Joséphine ange-gardien ${ }^{10}$," and Véronique Genest "Julie Lescaut ${ }^{11}$." Then, his or her career may be limited to jobs on the same network, as this actor notes:

"If you really are a TF1 star, you're not going to go work on France $2^{12}$, or, rather, if you're a star on France 2, TF1 won't want you." (Actor, Interview, 2012.)

The competition between networks is refracted at the level of artistic careers. Many actors thus participate as "guests" with small roles on other one-off shows or series from the network. The artist's name is then preceded by "guest starring" in the opening credits to distinguish him or her from lesser-known artists in the cast. Mobility

9. Navarro was a detective series broadcast on TF1 between 1989 and 2007 in which the title role, Inspector Navarro, was played by French actor Roger Hanin.

10. Joséphine ange-gardien [Josephine the Guardian Angel] is a comedydrama broadcast on TF1 since 1997. Mimie Mathy, a comedian, became the leading actress and co-producer of the series.

11. Julie Lescaut was a detective series broadcast on TF1 between 1992 and 2014, Véronique Genest was one of the first actresses to play a female police chief onscreen in France.

12. France 2 is the leading public television network in France. 
avec des artistes de moindre notoriété. La mobilité est alors principalement interne à la chaîne. L'empreinte du rôle majeur et de l'image de la chaîne promettent une sécurité d'emplois télévisuels en réduisant cependant l'espace des possibles au dehors.

Une deuxième forme de mobilité de chaîne concerne les emplois semi-récurrents. Ces emplois font partie de la distribution élargie, et recouvrent des rôles en appui du héros (conjoint·e, enfant, parents, collègue, ami·e, etc.). Ces emplois, de quelques jours de tournage, moins marquants, ouvrent néanmoins à une mobilité de chaîne plus fluide. Le «nom » des acteurs est, en effet, un atout monnayable auprès des responsables de castings qui parfois gèrent les recrutements pour d'autres séries, et sont crédibles auprès des sociétés de productions d'autres chaînes, conduisant ainsi à des visionnages en replay, au téléchargement et à la réception médiatique des programmes auxquels ils participent. Par exemple, des acteurs ayant fait leurs armes dans des séries du service public, dans des distributions comprenant plusieurs acteurs récurrents dites "chorales " comme Un village français ${ }^{13}$, sont employés dans des séries comme Engrenages ${ }^{14}$ ou Le Bureau des légendes ${ }^{15}$ sur Canal+, voire obtiennent des rôles principaux dans des unitaires des différentes chaînes. Le nom de l'artiste et son identification par les autres chaînes, les sociétés de production et les responsables de casting, ouvrent à d'autres programmes télévisuels hexagonaux. C'est la réputation de bon·ne comédien·ne qui assure alors l'insertion dans les distributions de séries.

13. Cette série a été diffusée sur France 3 entre 2009 et 2017

14. Cette série judiciaire est diffusée sur Canal+ depuis 2005. C'est une des séries françaises les plus exportées depuis sa création.

15. Cette série d'espionnage à succès est diffusée sur Canal+ depuis 2015. is therefore mainly internal to a network. Being marked by a major role and by the network's image guarantees a steady stream of television work, but also reduces the space of outside possibilities.

A second form of network mobility has to do with recurring roles. These roles are part of the wider cast that extends beyond lead roles and includes supporting roles (the protagonist's spouse, child, parent, colleague, friend, etc.). These jobs, which entail only a few days of shooting, are less defining, but open the way to a more fluid network mobility. The "name" of an actor who plays such a role is, in fact, a commodity that can be monetized with respect to casting heads who sometimes oversee recruiting for other series and have credibility with the production companies of other networks. The result is that the programmes in which actors participate are streamed online, downloaded, and featured in the media. For example, actors who cut their teeth on public network series as part of so-called "ensemble" casts made up of multiple recurring roles-for example, A French Village (Un village français) ${ }^{13}$ - may be hired for series such as Spiral (Engrenages) ${ }^{14}$ or The Bureau (Le Bureau des legends $)^{15}$ on Canal+ or may even land starring roles in programmes on other networks. The artist's name and recognition from other networks, production companies, and casting directors open the door to other French television shows. It is his or her reputation as a good actor that ensures he or she will find work on other television series.

13. This historical series on the Second World War was broadcast on France 3 between 2009 and 2017.

14. This legal drama has been broadcast on Canal+ since 2005. Since its debut, it has been one of the most exported French series.

15. This successful spy series has been broadcast on Canal+ since 2015 
Enfin, la troisième forme de mobilité est favorisée par l'internationalisation de la carrière. Les fictions télévisuelles très exportées ${ }^{16}$ peuvent être des catalyseurs pour solliciter des emplois dans le monde anglophone, voire dans les programmes coproduits avec d'autres pays. Ainsi en est-il de cet acteur cité en exemple par une agente dont la carrière a débuté dans une série pour adolescents à la fin des années 1990 sur TF1, diffusée désormais par Netflix ; il joue ensuite dans quelques séries sur France Télévision avant d'intégrer les séries les plus cotées de

Canal+, puis d'être recruté dans des séries anglophones.

"Tenir le rôle », signer pour une deuxième, voire une sixième saison, garantit un salaire, tandis qu'enchaîner des rôles dans des séries, intégrer la distribution d'un unitaire de "prestige » contribue à façonner l'image et à construire de possibles mobilités dans l'espace audiovisuel. Ces mobilités peuvent se traduire par l'accès à l'espace cinématographique, point de mire de la plupart des artistes.

\subsection{Un capital médiatique convertible au cinéma}

$\mathrm{Si}$ incarner des personnages récurrents et se voir assigner l'étiquette de "comédien ne de télévision » peuvent " griller » momentanément des opportunités professionnelles, en revanche, certains formats, par effet d'homologie structurale, ouvrent des portes pour rejoindre le cinéma, comme le souligne cette agente :

« II vaut mieux faire des petites vignettes rigolotes parce que le cinéma vient vous chercher puisque le cinéma maintenant développe beaucoup les comédies : on repère

16. Selon les chiffres annuels du CNC (Centre national de la cinématographie et de l'image animée), l'exportation des fictions françaises est à la hausse depuis sept ans (CNC $2018: 24-25)$
Finally, a third form of mobility is made possible by internationalizing one's career. Thus, television dramas that are widely exported ${ }^{16}$ can be catalysts for acquiring work in the English-speaking world or as part of programmes co-produced with other countries. This is what happened with one actor cited by an agent: his career began with a role on a young adult series on TF1 in the late 1990s, which was picked up by Netflix; he then performed in a few series on France Télévision before joining some of the most successful shows on Canal+ and eventually being recruited onto Englishlanguage series.

"Playing the part," signing on to a second, or sixth, season guarantees a salary, whereas lining up one role after another in different TV series, and joining the cast of a "prestige" production shapes an actor's image and creates potential for mobility within the audiovisual space. This mobility can allow an actor to access the space of cinema, a focal point for most artists.

\subsection{Media Capital that can be Converted into Film Roles}

Although playing recurring characters and being labelled a "television actor" can temporarily "zap" an actor's professional opportunities, on the other hand, some formats open the way to movies, as this agent emphasizes:

"It's better to do small, funny vignettes because then the movies will come looking for you, since these days a lot of

16. According to the yearly figures from the CNC (Centre national de la cinématographie et de l'image animée), the export of French film and television drama has been on the rise for the past seven years (CNC 2018: 24-25) 
donc quelqu'un qui est drôle et on peut l'emmener au cinéma. » (Agente, entretien, 2018.)

Des programmes courts, comme Un gars, une fille ${ }^{17}$, sont cités en exemple de format tremplin pour accéder au cinéma commercial. La montée en visibilité du nom d'artistes du petit écran facilite, en ce sens, l'accès au marché des emplois cinématographiques, quitte à tenter d'opérer des infléchissements de carrière vers le cinéma d'auteur, comme l'ont fait les comédien.ne-s de ce programme, Jean Dujardin et Alexandra Lamy. Se soumettre à ce critère de sélection médiatique, jouant sur la réduction de l'incertitude économique, est donc un levier de promotion de carrières.

Dans cetteéconomie dessingularités (Karpik2007), le nom, construit dans des interventions télévisuelles régulières (participations à des talk-shows, présentatrices météo ou humoristes), permet une circulation entre les différents espaces professionnels. Les séries télévisées sont, dès lors, des vitrines qui fonctionnent comme des lieux de repérage stratégiques pour accéder au cinéma. Les jeunes comédien'ne-sy tentent leurs chances, et les sociétés de production en font un espace de veille. "Peu importe le format pourvu qu'on ait l'emploi ", voilà comment on pourrait résumer le travail de placement au quotidien. Le nom, comme capital médiatique, offre ainsi des profits monnayables au cinéma. Construire ces mobilités d'un espace à l'autre suppose généralement de changer d'agence pour intégrer des structures où les agentes rentabilisent ces cotes dans des productions cinématographiques. II s'agit, dès lors, de travailler à la conversion du capital médiatique construit à la

17. Format court diffusé au cours des années 2000 sur France 2 avant 20 h don l'acteur principal Jean Dujardin, après s'être reconverti au cinéma, a obtenu un Oscar pour The Artist de Michel Hazanavicius (2011). comedy films are in development, so they are always looking for funny people to bring into movies." (Agent, Interview, 2018.)

Short programmes such as Un gars, une fille ${ }^{17}$ are cited as examples of formats that can serve as springboards to get into commercial cinema. In this way, the increased visibility of an actor's name on the small screen can facilitate access to the job market for film, and can even lead to an actor orienting his or her career towards arthouse cinema, as the stars of Un gars, une fille, Jean Dujardin and Alexandra Lamy, for example, have done. Subjecting oneself to this criterion of media selection, gambling on a reduction in economic uncertainty, can thus serve as a lever in promoting one's

career.

Within this economy of singularities (Karpik 2011), an actor's name, built on television regular appearances (in talk shows, weather broadcasts, or comedy shows) allows circulation between various professional spaces. Television series are thus like window displays that function as strategic scouting sites for accessing movie work. Young actors try their luck there, and production companies keep watch over them. "Format doesn't matter as long as you have work" thus sums up the everyday work of placing actors. Constructing such mobility between different spaces generally means changing agencies and joining organizations where agents convert television popularity into film roles. It then becomes a matter of converting media capital built on television into symbolic and artistic profit in order to cross the border into the more prestigious field of cinema. In addition to building up the media capital attached to a name, landing

17. This was a short-format show broadcast on France 2 during the 2000 s before the 8pm TV news; it starred Jean Dujardin, who later turned to cinema and won an Oscar for his performance in Michel Hazanavicius's 2011 film The Artist. 
télévision en profit symbolique et artistique pour parvenir à franchir la frontière du champ cinématographique, plus prestigieux. Outre la construction du capital médiatique nominatif, se placer dans des séries comprend des enjeux et usages professionnels relevant de la socialisation professionnelle et de l'intériorisation des règles du métier dans une logique de production industrielle.

\section{Enjeux et usages du placement dans les séries} télévisées

Les enjeux de placements, articulant intérêts symboliques et matériels, se traduisent en combinaisons multiples pour réaliser des projets dans un ou plusieurs des secteurs d'emploi dramatique. Ces combinaisons se dessinent au gré des aspirations personnelles et de l'horizon des possibles, puisque ces carrières par projet (Menger 1997a) sont indéterminées et incertaines (Menger 2005, 2009, 2012 ; Pilmis \& Cardon 2013). Pour les comédien·ne·s, chaque placement est l'occasion de construire un carnet d'adresse et de capitaliser sur les rencontres à long terme.

\subsection{Les séries comme droit d'entrée professionnel}

Le travail de valorisation réalisé par les agentes s'effectue à toutes les étapes de la vie professionnelle, en tentant d'être au plus près des aspirations de la clientèle, évaluées en fonction des possibles. Le placement sur les séries télévisées fait partie intégrante de la socialisation des impétrant $\cdot e \cdot s$, voire fait office, selon les termes d'une agente, d'« études payées ». En effet, pour les plus jeunes, l'offre d'emploi est particulièrement ouverte à la télévision (Menger 1997b) où la codification des emplois est très stéréotypée. Ainsi, certaines chaînes privées demandent aux agentes de leur présenter des gens « beaux » et jeunes, surtout pour les jeunes femmes, comme le souligne cette agente a role on a series involves professional implications and customs that stem from professional socialization and the internalization of the rules of the trade within a logic of industrial production.

\section{The Implications and Customs of Actor Placement on TV Series}

The implications of actor placement, where material and symbolic interests are intertwined, are expressed in multiple combinations that lead to projects in one or more sectors of dramatic work. These combinations are shaped by an actor's personal aspirations and the horizon of possibilities, since these project-based careers (Menger 1997a) are indeterminate and uncertain (Menger 2005, 2012; Pilmis \& Cardon 2013). For actors, each placement is an opportunity to network and to capitalize on encounters over the long term.

\subsection{TV Series as Professional Gateways}

The work of valorization performed by agents occurs at every stage of an actor's professional life; agents try to stay as close as possible to their clients' aspirations, which they assess on the basis of what is possible. Being placed on a television series is an integral part of aspiring actors' socialization, and even serves as a kind of 'paid learning' according to one agent. Indeed, for the youngest actors, the television job market, where the codification of jobs is highly stereotyped, is particularly open (Menger 1997b). Thus, some private networks ask agents to show them 'beautiful' young people, especially young women, as this agent emphasizes: 
«On sait, oui c'est public, chez [chaîne privée], pour les séries, ils veulent en général des gens beaux : entre deux personnes, entre une qui joue mieux mais qui est moins jolie et l'autre, ils vont prendre la plus jolie ! » (Agente, entretien $1^{\mathrm{er}}$ sur 2, 2013.)

Un sens pratique, rodé par l'expérience et les descriptions données par les responsables de castings, conduisent les agentes à classer en amont leur clientèle selon les offres d'emploi des chaînes de télévision. Par exemple, lors d'observations dans une agence, une agente me montre le trombinoscope de ses clientes en désignant celles qui correspondent au profil d'une grande chaîne privée, pour laquelle les comédiennes doivent être belles, minces et plutôt blanches ${ }^{18}$. Ces types physiques contrastent avec les « gueules » dont les visages sont, y compris pour les hommes, moins lisses, moins formatés aux attentes de certaines grandes chaînes, et que l'on peut placer sur des séries comme celles de Canal+, me dit-elle. Pour les agentes, il s'agit au départ de les « placer partout », sur tous les castings pour que leurs client·e.s se fassent connaître. Dès lors, être repéré·e par une responsable de casting et être recruté·e par une production est un premier critère de professionnalité.

\section{2. Être payé·e pour faire son métier}

Les petits rôles dans des séries pour lesquels les droits d'entrée sont peu sélectifs, correspondent à une ou quelques journées de tournage. Intégrer ces « produits » permet de faire son travail, relationnel et dramatique, en étant rémunéré. Pierre

18. Nombre de débats portent, en France, sur la sous-représentation des femmes dans les fictions cinématographiques et télévisées en raison de leur âge par exemple (le «tunnel de la comédienne de cinquante ans ») mais aussi sur les emplois stéréotypés liés au type physique et la couleur de peau. Cf. le livre Noire n'est pas mon métier d'un collectif de comédiennes formé par Aïssa Maïga (Collectif, 2018).
"Everyone knows that at [privately-owned network], for series, they usually want beautiful people, and if they are choosing between two actors or actresses, one of whom acts better but is less pretty than the other, they will choose the prettier one!" (Agent, Interview, 1st of 2, 2013.)

Agents' pragmatism, informed by their experience and the descriptions provided by casting directors, leads them to categorize their clientele according to the job offers they receive from networks. For example, during one of my observation sessions at an agency, an agent showed me the face book of her clients and pointed out those that matched the profile sought by a major private network that insists on actresses who are beautiful, thin, and mainly white ${ }^{18}$. She told me that such physical types contrast with "mugs" - faces, including men's, that are less smooth and less fitted to the expectations of certain major networks, but that can be placed on series on Canal+, for example. Initially, agents seek to place their actors everywhere, sending them to every audition so that they become well known. The next step is to get them noticed by a casting director and recruited for a production, the first mark of professionalism

\subsection{Getting Paid to Do One's Job}

Minor roles on series that are not very selective in casting usually mean just one or a few days of shooting. Participating in these "products" allows actors to do their jobs-both in terms of networking and in terms of dramatic work-and get paid. Pierre

18. There are, in France, many ongoing debates about the under-representation of women in film and television, in particular older women ("the disappearance of the 50-year-old actress") as well as about stereotyped parts related to body type and skin colour. See the collective book Noire n'est pas mon métier [Being black is not my job] written by a group of actresses formed by French actress Aïssa Maïga (Collectif 2018). 
Deladonchamps, comédien prisé du cinéma d'auteur français ${ }^{19}$, raconte ses premiers pas dans des séries jugées « un peu nul[les] »

(Familles d'accueil, Central nuit, RIS police scientifique) :

P. Deladonchamps : « Le tout premier casting, je l'ai réussi, c'était encourageant. II [son agent] était content de m'avoir choisi, j'étais content d'avoir été pris, c'était Famille d'accueil, [une série] sur France $3^{20}$ [...] C'est là que j'ai fait mes armes. Et c'est très important, ce genre de travail, pour un acteur, parce qu'on peut ne pas trouver cela prestigieux - un petit peu nul, trop populaire, trop ci, trop ça -, en même temps, pour nous, c'est une chance [...] ça m'a appris mon métier. On apprend à l'école avec des copains, avec un texte, mais il n'y a pas de caméras, on n'est pas payé pour ça, on n'a pas de pression. » (Interview, France Inter, 2018.)

Ces emplois sont donc une étape charnière pour être reconnu comme comédien·ne professionnel·le dans des activités où le travail gratuit fait partie intégrante de l'activité (Cardon \& Pilmis 2013), permettant ainsi de travailler le nombre d'heures nécessaires pour pouvoir accéder au statut d'intermittent·e du spectacle (Menger 2011 ; Grégoire 2013 ; Katz 2015), et de donner des preuves de qualité monnayables par les agentes pour négocier de prochains contrats. En outre, ces emplois socialisent aux logiques industrielles

de production.

\subsection{Incorporer la logique industrielle de production}

La durée des tournages de fictions audiovisuelles est très courte: un épisode de 52 minutes peut être tourné en dix jours, un unitaire de 90 minutes en vingt-et-un jours, d'où une acclimatation à un

19. Pierre Deladonchamps a reçu en 2014 le César du meilleur espoir masculin pour son rôle dans L'Inconnu du lac d'Alain Guiraudie.

20. France 3 est la deuxième chaîne de service public en France.
Deladonchamps, a well-respected arthouse actor ${ }^{19}$, recounts his first steps on series that were considered "kind of dumb" (Familles d'accueil, Central nuit, $\underline{R}$ IS police scientifique:

P. Deladonchamps: "My very first casting, I got the part, and that was encouraging. He [my agent] was happy to have chosen me, I was happy to have been cast, and it was [the series] Famille d'accueil on France $3^{20}[\ldots]$ That's where I cut my teeth. And this kind of work is really important for an actor because you might think it's not prestigious, it's kind of dumb, it's too mainstream, too this, too that, but at the same time, for us, it's an opportunity [...] it taught me my craft. At school you learn with your friends, from a text, but there are no cameras, you don't get paid, and there's no pressure." (Interview, France Inter Radio, 2018.)

Thus, this kind of work is pivotal to becoming recognized as a professional actor in a sector where unpaid work is integral to the job (Cardon \& Pilmis 2013), and it allows actors to accrue hours and thereby obtain the status of "intermittents du spectacle" (entertainment industry contract workers) (Menger 2011; Grégoire 2013; Katz 2015); it also allows them to prove their worth, which agents can use in negotiating their next contracts. Furthermore, these jobs socialize them in the industrial logics of production.

\subsection{Incorporating the Logic of Industrial Production}

The length of shoots for television shows is quite short: a fiftytwo-minute episode can be shot in ten days and a ninety-minute

19. In 2014 Pierre Deladonchamps received a César for Best New Actor for his role in Stranger by the Stranger by the Lake (L'Inconnu du lac) by Alain Guiraudie.

20. France 3 is the second public television network in France. 
rythme de travail intense pour fabriquer ces programmes. La participation au tournage et son aboutissement heureux quand on figure à l'écran constituent une mise à l'épreuve professionnelle des dispositions d'ajustement aux contraintes budgétaires et temporelles de ces productions :

«Latélévision, c'est intéressant pour des comédiens quant à l'apprentissage du métier. L'avantage et l'inconvénient, c'est qu'à la télévision on n'a pas le temps, on a moins le temps [...] il faut que ça enchaîne, il faut que ça envoie : il faut être bon, tout de suite. En revanche, attention! Si tu n'es pas bon, ca peut se voir aussi ensuite : donc je trouve ca bien, aussi, comme expérience. » (Agent, entretien, 2015.)

Ces tournages sont des épreuves sélectives. Placer de jeunes client.e.s dans les distributions des séries fait partie intégrante de la période probatoire d'environ deux ans pour sortir du lot (Pilmis 2008, 2013). La capacité d'ajustement aux normes d'organisation industrielle du travail entre en ligne de compte pour décrocher le label de «bon'ne comédien'ne » et être ainsi reconnu·e comme "pro » (Boussard, Demazière, Milburn 2010). En effet, rares sont les répétitions et les lectures en amont. II s'agit de tourner à flux tendu, notamment dans le cadre de feuilletons quotidiens :

«Qu'on n'aime pas les histoires, ce n'est pas un souci mais je trouve que, quand on est un bon comédien, on s'en sort toujours même si le texte n'est pas... voilà... Tout au moins on dit : "Il est pas mauvais !", et s'il s'en sort dans Plus belle la vie ${ }^{21}$ avec un texte qui n'est pas folichon, folichon, vu les difficultés de tournage - parce qu'ils tournent très, très

21. Plus belle la vie est un feuilleton quotidien extrêmement populaire, diffusé sur France 3 depuis 2004. Voir, dans le présent numéro, l'article de Muriel Mille publié dans ce dossier. programme in twenty-one days, which means actors must acclimatize to an intense work pace. Participating in a shoot and having a successful on-screen appearance means proving one's capacity to adapt to the budget and time constraints of these productions:

"I find television work to be important for actors to learn the profession. The advantage, and the difficulty, is that in television you don't have time, you have less time [...] you have to be quick and efficient, you have to be good the first time. On the contrary, if you're not good, it's immediately obvious, and for this, I think that's also a useful experience." (Agent, Interview, 2015.)

These shoots are competitive tests. Placing young clients in the cast of a series is an integral part of the approximately two-year trial period during which actors have a chance to stand out from the crowd (Pilmis 2008, 2013). Adjusting to the standards of the industrial organization of work is a factor in gaining the label of "good actor" and being recognized as a "pro" (Boussard, Demazière, Milburn 2010). Rehearsals and read-throughs ahead of time are rare. Actors must shoot on a "just-in-time" basis, in particular when it comes to daily soap opera shows:

“Whether we like the story or not, it doesn't matter, but I find that when an actor is good, he will always manage, even if the text isn't... well... at the very least you can say 'He's not bad!' and if he succeeds on Plus belle la vie ${ }^{21}$ with a text that's not that great, given the difficulty of shooting - because they shoot really, really fast-well then to the contrary, you can say this is an actor who will succeed on other stages. So

21. Plus belle la vie is a very popular French daily soap-opera, broadcast on France 3 since 2004. See the article by Muriel Mille, in that same dossier. 
vite - eh bien, au contraire, on se dit que c'est un comédien qui s'en sortira sur d'autres plateaux ! Donc aujourd'hui, ce n'est plus trop négatif. » (Agente, entretien, 2013.)

L'expression d'un savoir-faire technique reconnu comme «bon » dans des programmes jugés de moindre qualité artistique procure paradoxalement un bénéfice à l'exercice du métier réalisé dans ce contexte. Ces tournages sont, en quelque sorte, des lieux de dressage professionnel où les artistes incorporent de concert les contraintes matérielles de production et le travail d'art dramatique. Des séries à succès comme Plus belle la vie ont ainsi gagné en légitimité, y compris pour de jeunes scénaristes, qui intègrent les équipes pour vivre de leur métier et consolider certaines techniques d'écriture (Mille 2013) en vue de développer eux-mêmes des séries télévisées, voire d'écrire pour le cinéma. Ces apprentissages vécus dans l'espace des séries contribuent au développement des discours qui tendent à soutenir l'effritement des frontières entre les emplois télévisuels et cinématographiques.

On constate, en effet, depuis une dizaine d'années, que la concurrence sur le marché de l'emploi télévisé s'est tendue, en raison de l'affluence de comédien'ne-s dont la réputation était déjà faite au cinéma. La rentabilisation du nom forgé au cinéma, transféré dans l'espace de la production télévisée, produit un effet paradoxal : la légitimité du genre " série » déclasse en effet les comédien·ne·s dont le capital spécifique est attaché à la télévision, tandis que le recrutement de comédien.ne.s réputé.e.s au cinéma contribue, en revanche, au prestige de ces mêmes séries. Le pouvoir de diffusion des chaînes conduit ainsi les responsables de leurs programmes à fixer comme critère de sélection des castings où ne figurent, comme nous l'explique une directrice de casting, que « des noms de théâtre ou de cinéma » pour afficher un programme « chic » dont les « noms » induisent la qualité de la série. now it's no longer such a negative thing." (Agent, Interview, 2013.)

Displaying "good" technical know-how on programmes considered to be of lesser artistic quality is, paradoxically, advantageous to practising one's craft in this context. These shoots are like professional training sites where artists must incorporate both material production constraints and the work of dramatic art. Successful series such as Plus belle la vie have thus gained legitimacy, including among young screenwriters, who join their writing teams in order to make a living and to strengthen certain writing techniques (Mille 2013) so that they might themselves one day develop television series or even write for movies. Such apprenticeships within the space of series contribute to the development of the various discourses on the blurring of borders between television jobs and cinema jobs.

We can observe that over the past ten or so years, competition for TV jobs has increased due to an influx of actors who have already established a reputation in film. Profiting from a name established in cinema and transferred to the space of television has a paradoxical effect: the legitimization of the "series" genre in fact downclasses actors whose specific capital is only attached to television. In contrast, recruiting well-known film actors to television contributes to the prestige of these series. The distribution power of networks thus induces their heads of programming to set up castings that include only "names from theatre or cinema," as one casting director explained to me, so that they can then announce a "chic" programme whose "names" suggest the quality of the series. 


\section{La concurrence des « noms » de cinéma}

Depuis la crise de 2008, la polémique sur les salaires des stars de cinéma, lancée par le distributeur Vincent Maraval dans le journal Le Monde le 28 décembre 2012, et après quelques échecs retentissants de longs métrages à budgets conséquents dont les castings d'acteurs connus n'ont pas été rentabilisés en salle, les productions ont été contraintes de réviser leurs budgets en plafonnant les salaires et en réduisant la durée des tournages. Depuis les années 2010, en revanche, du côté télévisuel, des politiques publiques ont été mises en œuvre pour revaloriser les séries hexagonales très concurrencées par les séries anglophones. Les transformations technologiques, avec notamment le développement de plateformes numériques comme Netflix, OCS ou Amazon, ont contribué à la montée en qualité des séries françaises à visée exportatrice. De plus, le pouvoir grandissant des diffuseurs, comme les chaînes de télévision hertziennes, elles-mêmes soumises à la concurrence de ces plateformes, les a conduit à investir la production de séries télévisées. Celles-ci sont d'ailleurs devenues des pratiques culturelles en expansion

(Donnat 2009).

Les stratégies distinctives des chaînes de télévision pour construire la légitimité et l'originalité de leurs programmes se sont traduites par une augmentation des moyens de production alloués à certains formats, tels les 52 minutes. Elles embauchent aussi des cinéastes connu·e.s et consacré·e·s (Tonie Marshall, Éric Rochant, Cédric Klapisch, Thomas Lilti, etc.). Et ce, dans un contexte où les séries occupent les créneaux horaires longtemps réservés aux longs métrages, réalisant ainsi depuis une dizaine d'années de meilleurs scores d'audience que les films. La montée en valeur des séries tient en outre à l'emploi de comédien·ne·s consacré·e·s au cinéma. La division du travail territorialisée s'estompe en accroissant la

\section{Competition From Movie "Names"}

Since the economic crisis of 2008 , the polemic against movie stars' salaries-a polemic launched by the distributor Vincent Maraval in the French newspaper Le Monde on 28 December 2012, following the spectacular failure of several high-budget feature-length films whose high-profile casts did not generate box office profits-productions have been obliged to revise their budgets by capping salaries and shortening the length of shoots. However, since the 2010s, public policies have been established to promote French television series, which face stiff competition from English-language shows. Transformations in technologyin particular the development of digital platforms such as Netflix, OCS, and Amazon-have contributed to increasing the quality of French series intended for export. In addition, the growing power of broadcasters, including traditional television networks, which are themselves subject to competition from these platforms, has led them to become involved in producing television series. They are now recognized cultural practices in expansion in France (Donnat 2009).

The distinctive strategies television networks used to build the legitimacy and originality of their programmes, translated into increased production resources allocated to certain formats, for example, the fifty-two-minute format. Networks also hire wellknown, established filmmakers (Tonie Marshall, Éric Rochant, Cédric Klapisch, Thomas Lilti, etc.) for television series which now occupy time slots that were reserved for feature films: over the past ten years, series have out-performed films in terms of viewership on French television. The increased value of series also stems from the participation of established film actors. The territorial division of labour becomes blurred as competition increases within television, 
concurrence sur le terrain de la télévision, au détriment de celles et ceux qui ont construit un capital spécifique à cet espace audiovisuel.

\subsection{Le déclassement des comédien·ne·s de télévision}

Intégrer la distribution de séries prestigieuses à connotation cinématographique ajoute, si l'on peut dire, un supplément d'art à la réputation des comédien·ne·s. Reste que l'emploi de premiers rôles auparavant attribués aux comédien·ne·s de télévision fait rétrograder ces dernier.e.s sur les deuxièmes et troisièmes rôles. Les emplois de premier plan leur sont dès lors moins accessibles, car la notoriété acquise au cinéma valorise certes les programmes mais au détriment des comédien·ne·s, comme l'explique cet agent :

«En ce moment, on se retrouve avec une concurrence déloyale. Vous débarquez avec un comédien assez connu à la télévision, comme j'ai vécu le cas avec [acteur récurrent de série] qui est vraiment un acteur de télévision sur une série de TF1 : il a été présenté à la chaîne pour les deux ou trois rôles principaux, et en fait ils ont pris [acteur de cinéma ayant joué dans des comédies à succès] [qui] n'a jamais fait de télévision. » (Agent, entretien, 2013.)

Le rapport de production symbolique (Naudier 2018a), qui classe, divise et hiérarchise en constituant le nom en " monopole de singularité " (Naudier 2018b) convertible dans les différents espaces de production symbolique, accroît les inégalités statutaires et salariales aux dépens des comédien'ne-s de télévision depuis le début des années 2010. À la clôture des marchés de travail entre cinéma et télévision se substitue une polarisation des emplois. Sous couvert d'une plus grande fluidité entre les espaces se dessine en réalité un rapport asymétrique quant au pouvoir de circuler, et quant au sens de circulation. to the detriment of those who have built up capital specific to that space.

\subsection{The Downclassing of TV Actors}

Joining the cast of a prestigious series with cinematic connotations adds an artistic supplement, so to speak, to an actor's reputation. However, casting movie actors in principal roles that previously would have gone to television actors pushes the latter into secondary and tertiary roles. Top-level jobs become less accessible to them, for a reputation built in the cinema valorizes television programmes to the detriment of actors:

"Right now, we are dealing with unfair competition. When you show up with a rather well-known TV actor like I did with [actor with a recurring role on a series], who is a true TV actor with a TF1 series, he was presented to the network for two or three lead roles, but they went with [movie actor who played in successful comedies] [who] had never done television work." (Agent, Interview, 2013.)

Since the early 2010s, relations of symbolic production (Naudier 2018a), which classify, divide, and establish hierarchies by constituting artists' names as "monopolies of singularity" (Naudier $2018 b)$ that can be converted within the various spaces of symbolic production have increased inequalities in status and salary, to the detriment of television actors. The job markets for movies and television are no longer closed off to one another, but this closure has been replaced by a polarisation of jobs. Under the façade of greater fluidity between the two spaces exists a relation that is asymmetrical in terms of actors' ability to circulate and the directionality of that circulation. 


\subsection{La dialectique du déclassement et du reclassement} professionnel

Les habits neufs de la distinction fictionnelle sont, on l'a vu, portés à l'écran par des cinéastes et comédien·ne·s de cinéma. Toutefois, la concrétisation de ces projets est, en amont, façonnée par les intermédiaires, qu'il s'agisse des chaînes de télévision, des sociétés de production de fiction et des agents, intermédiaires de marché qui produisent l'information sur la valeur (Bessy \& Chauvin 2013). Le travail de communication médiatique autour de ces transferts contribue à enrichir symboliquement une catégorie de ces productions télévisuelles. En sorte que des stratégies de compensation du déclassement, que suppose l'investissement dans l'espace télévisuel jusqu'aux années 2010, se traduisent par un travail collectif de production de la croyance en la valeur de ces

programmes.

En quelques années, les séries hexagonales, sous l'effet du modèle de la montée en qualité des séries états-uniennes notamment, sont même devenues un objet de convoitise qui accentue la concurrence entre comédien.ne·s de cinéma.

«Porter une série » sur son nom, obtenir le premier rôle permet de maintenir la cote des artistes selon un ordre temporel où se joue la « dialectique du déclassement et du reclassement » (Bourdieu 1978 : 20). Selon le témoignage d'un auteur concerné, certaines agences commandent à leurs client·e.s scénaristes l'écriture d'une série pour des comédien·ne.s stars en «perte de vitesse ». Ces commandes sont, par ailleurs, propices aux packages (Bielby 1999) qui permetttent de placer plusieurs client·e.s (scénaristes, comédien·ne·s, cinéastes). Or, dans ce contexte de redistribution de l'ordre des légitimités, ce qui, jusqu'aux années 2000, était un signe de déclassement devient, dans les années 2010, un gage de

\subsection{The Dialectic of Professional Downclassing and Upclassing}

The new trappings of this distinction in fiction are, as we have seen, carried onscreen by filmmakers and movie actors. However, before that ever happens, these projects are made concrete by various intermediaries-television networks, producers, and agents-who create information relating to their value (Bessy \& Chauvin 2013). The work of media communication that surrounds these transfers contributes to symbolically enriching one category of television productions, and strategies to compensate for downclassingwhich, until the 2010s, was implied by investment in the space of television-are now expressed in a collective effort to produce belief in the value of these programmes.

In the space of a few years, and in particular, following the model of the leap in quality of series from the United States, French television series have even become coveted objects that intensify competition between movie actors.

For an artist to "carry a series" in his or her name, to land the lead role, makes it possible for him or her to remain popular within a temporal order where the "dialectic of downclassing and upclassing" plays out (Bourdieu 1984: 163). According to a screenwriter, some agents order their screenwriter clients to create series for star actors who are "losing momentum." Such orders often lead to the creation of "packages" (Bielby 1999), thanks to which agents can place several clients (screenwriters, actors, filmmakers) at once. Within this context of the reordering of legitimacies, what was a sign of down classing until the 2000s has become in the 2010s a token of staying active, even being "modern." The "system of 
maintien en activité, voire de « modernité ». L'« espèce d'instabilité structurale » (Bourdieu $1978: 18$ ) des cotes autorise celles et ceux qui peuvent encore capitaliser sur ces noms à en faire des garants de ces programmes.

Sous l'effet conjugué de transformations morphologiques et économiques, la montée en valeur et en visibilité des séries télévisées accroît la concurrence, non seulement entre comédien·ne·s de cinéma pour accéder à la télévision, mais aussi sur le terrain entre comédien.ne·s doté·e.s de légitimité. "Porter » ou « faire partie » d'une série est désormais un enjeu de classement des comédien.ne.s qui contribue à leur mise en valeur. Les agentes participent à cette mise en concurrence en travaillant au transfert de leur clientèle selon le moment de leur carrière. Ainsi " faire venir » dans une série des comédien-ne·s de cinéma fait l'objet de négociations avec certain·e.s client·e.s dont la carrière à succès s'est déroulée sous un régime de valeurs où travailler dans une série était un signe de décote professionnelle, comme le souligne cette agente :

« La première chose que je lui ai proposée, c'était une série : cela a été hyper dur à défendre. C'est un acteur de soixante ans, qui a son passé, qui a vécu avec l'idée de "les séries, c'est de la merde, c'est pour les fins de carrière, c'est pour quand on ne va plus au cinéma, quand les acteurs de cinéma sont recyclés à la télé", enfin, il avait vécu avec cette image-là. » (Agente, entretien, 2014.)

Les agentes, en tant que « stratèges de la notoriété » (Lizé, Naudier, Sofio 2014), travaillent à construire la mobilité des comédien·ne·s les plus réputé.e.s du cinéma vers la télévision. Elles réalisent un travail de conviction qui consiste notamment à transformer un signe de déclassement professionnel en un signe valorisant de structural instability" (Bourdieu 1984: 156) of ratings allows those who can still capitalize on their names to become the guarantors of these programmes.

Under the combined effect of morphological and economic transformations, the increase in the value and visibility of television series has heightened the competition not only between film actors to access television, but also among actors who have achieved legitimacy on television. "Carrying" or "belonging to" a series is now a factor in how actors are classified, and it contributes to establishing their value. Agents participate in this competition by working to transfer their clients from movies to television or vice versa, depending on where they are in their career. Thus, agents negotiate "bringing in" their movie actor clients for television series, some of these clients having had successful careers within a value regime where working on a series meant that one had fallen off professionally, as this agent emphasizes:

"The first thing I proposed to him was a series, and it was really hard to justify that. This is a 60-year-old actor, who has history, who had internalized the idea that 'series are shit, it's for the end of your career, for when no one goes to movies any more, when movie actors are recycled for television;' he had lived with that image." (Agent, Interview, 2014.)

As "strategists for fame" (Lizé, Naudier, Sofio 2014), agents work to create the mobility of the best-regarded movie actors towards television. They perform a work of persuasion that consists, in particular, in transforming a sign of professional downclassing into a sign that actors are continuing to do rewarding work when they 
maintien des comédien·ne·s en activité quand ils/elles intègrent ces programmes désormais convoités. La mobilité des comédien.ne·s du grand vers le petit écran a une fonction légitimante pour les séries télévisées françaises, tandis que, pour elles et eux, l'espace d'employabilité s'élargit.

\section{Conclusion : la victoire des «noms », les gagnant $\cdot e \cdot s$ de l'ennoblissement des séries}

La production de la valeur des séries télévisées s'ancre dans un contexte socioéconomique où l'exportation des programmes audiovisuels est un enjeu de concurrence internationale. En France, plusieurs rapports ${ }^{22}$ depuis les années 2000 vont dans le sens du soutien public à la création de séries télévisées (par l'intermédiaire du Centre national de la cinématographie et de l'image animée/CNC). L'Association française des critiques de séries (ACS) est créée en 2015, alors que plusieurs festivals à Cannes, Paris, La Rochelle et Lille, ainsi que des colloques et publications scientifiques, participent à l'ennoblissement du genre et à la hiérarchisation des programmes.

Les mécanismes de valorisation spécifiques à l'économie télévisuelle ont une rentabilité différentielle selon les segments commerciaux sur lesquels ils se situent. Dans ces stratégies d'insertion professionnelle qui font de chaque placement sur un projet un pari pour contrôler l'incertitude des carrières

22. Par exemple : "Crise et relance de la fiction française " (Club Galilée, avril 2010), «Pour une relance de la fiction française » (CSA/SESCA novembre 2010) et le rapport de la mission Chevalier « Fiction française. Le défi de l'écriture et du développement » (CNC, mars 2011), Hertzberg Laurence, Iris Bucher et Anne Landois, « Créer en France un festival des séries de renommée internationale » (rapport d'étude remis à la ministre de la Culture et de la Communication, Audrey Azoulay, en mars 2016). join these now-coveted programmes. The mobility of actors from the big to the small screen serves to legitimize French television series, while the space of employability expands for this category of actor.

\section{Conclusion: The Triumph of "Names", Those Who Gain From the Ennoblement of Series}

The value of TV series is produced within a socioeconomic context where the export of audio-visual programming is a matter of international competition. In France, several reports published after $2000^{22}$ have pushed for public support for the creation of television series (via the intermediary of the Centre national de la cinématographie et de l'image animée, CNC). The Association française des critiques de séries (ACS) [French association of critiques of TV series] was created in 2015, and various festivals in Cannes, Paris, La Rochelle, and Lille, as well as conferences and scholarly publications, have contributed to the ennoblement of the genre, and to establishing a hierarchy between programmes.

The mechanisms of valorization specific to the television economy are profitable to a varying degree depending on the commercial segments in which they are situated. Within these strategies for professional integration, which mean that each placement on a project is a gamble to gain control over the uncertainty of an acting

22. "Crise et relance de la fiction française" (Club Galilée, April 2010); "Pour une reliance de la fiction française" (CSA/SESCA, November 2010); the report published by the Chevalier mission, "Fiction française. Le défi de l'écriture et du développement" (CNC March 2011); and "Créer en France un festival des series de renommée internationale (report submitted to the Minister of Culture and Communication, Audrey Azoulay, March 2016, by Laurence Hertzberg, Iris Bucher, and Anne Landois). 
professionnelles, on constate, certes, des conversions de capitaux de la télévision vers le cinéma. Mais ces conversions comportent une variable cachée : celle de la mobilité d'une agence indépendante vers de plus grosses structures. Réputées "dénicheuses ", les petites agences recrutent leur clientèle dans les cours de théâtre et, grâce à leurs réseaux auprès des responsables de casting, font « monter » les noms en lançant ces carrières. Or, les grosses agences «polycéphales » (Naudier \& Roueff 2013) qui, elles, spéculent généralement sur les petits noms, sont précisément celles par qui les transferts vont se faire vers le cinéma. Ces agences recomposent ainsi le marché des emplois en affectant les meilleurs rôles télévisuels aux artistes doté·e·s d'une forte notoriété au cinéma. Ces agences ont donc intérêt à défendre les circulations entre les espaces professionnels pour procurer des emplois à leur clientèle. En sorte que les discours de façade tenus par les artistes sur la dilution des frontières symboliques entre le genre sériel et le genre cinématographique traduisent en réalité une concurrence entre comédien·ne·s de cinéma, mais déplacée dans l'espace télévisuel. Ces discours qui tendent à nier la division des territoires professionnels, en célébrant la libre circulation des comédien·ne·s, masquent des luttes pour préserver une position dominante symboliquement, temporellement et commercialement dans l'espace des séries, dont le crédit s'accroît à mesure des transformations technologiques, notamment numériques. Saisir la reconfiguration progressive d'un espace sériel au prisme du placement des comédien.ne·s met ainsi au jour combien la conversion des capitaux d'un espace à l'autre est asymétrique. La mobilité des noms de cinéma vers la télévision, comme mécanisme de valorisation, est ainsi un des leviers de l'ennoblissement du genre sériel au détriment des comédien·ne·s de télévision.

Delphine Naudier CNRS/Centre de recherches sociologiques et politiques de Paris - Cultures et sociétés urbaines (Cresppa - $\underline{\mathrm{CSU}})$ career, we observe conversions of capital from television towards movies. But these conversions include a hidden variable: mobility from an independent agency towards a larger organization. Known for their scouting efforts, small agencies recruit their clients from theatre classes and, thanks to their connections to casting directors, "raise" names by launching careers. But it is through large, "multiheaded" agencies (Naudier \& Roueff 2013), which usually speculate on lesser names, that transfers towards movies are carried out. In this way, these agencies reshape the job market by procuring the best television roles for artists who have established significant fame in film. These agencies therefore have an interest in protecting the circulation between professional spaces in order to procure work for their clients. And thus, artists' surface discourse on the dissolution of the symbolic borders between the series genre and the film genre in fact expresses competition between movie actors, which has shifted to the space of television. This discourse denying the division between professional territories by celebrating the free circulation of artists masks struggles to preserve a symbolically, temporally, and commercially dominant position within the space of series, the respectability of which is increasing with transformations in technology, in particular digital technology. Analysing the gradual reconfiguration of the space of series through the lens of actor placement reveals how asymmetrical the conversion of capital from one space to another actually is. Thus, as a mechanism of valorization, the mobility of movie names towards television acts as a lever that ennobles the genre of the television series to the detriment of television actors.

Delphine Naudier CNRS/Centre de recherches sociologiques et politiques de Paris - Cultures et sociétés urbaines (Cresppa - $\underline{\text { CSU }}$ ) 


\section{Références bibliographiques}

BECKER Howard (1988). Les Mondes de l'art. Traduit de l'anglais par Jeanne Bouniort. Paris, Flammarion.

Bessy Christian \& EYMARd-Duvernay François (dir.) (1997). Les Intermédiaires du marché du travail. Paris, Presses universitaires de France.

Bessy Christian \& Chauvin Pierre-Marie (2013). « The Power of Market Intermediaries : From Information to Valuation Processes ». Valuation studies, 1(1) : 83-117.

Bessy Christian \& ChAUVIN Pierre-Marie (2014). « Intermédiaires de marché ». In GrossetTI Michel, Zalio Pierre-Paul, Chauvin Pierre-Marie (dir.), Dictionnaire sociologique de l'entrepreneuriat. Paris, Les Presses de Sciences Po : 361-379.

Bielby Denise \& Bıelby William T. (1993). "The Hollywood "Graylist" ? Audience Demographics and Age Stratification among Television Writers ». In CANTOR M.G. \& ZollaRs C. L. (dir.), Current Research in Occupations and Professions. Greenwich, JAI Press, vol. 8 : 141-172.

Bielby Denise D. \& Bielby William T. (1999). "Organizational Mediation of Project-Based Labor Markets : Talent Agencies and the Careers of Screenwriters." American Sociological Review, 64(1) : 64-85.

BOURDIEU Pierre (1978). « Classement, déclassement, reclassement 》, Actes de la recherche en sciences sociales, $24: 2-22$.

Boussard Valérie, Demazière Didier, Milburn Philip (dir.) (2010). L'Injonction au professionnalisme. Analyses d'une dynamique plurielle. Rennes, Presses universitaires de Rennes.

Brigaud-Robert Nicolas (2011). Les Producteurs de télévision. Socioéconomie d'une profession. Saint-Denis, Presses universitaires de Vincennes.

\section{References}

BECKER Howard S. (1982). Art Worlds. Berkeley, University of California Press.

Bessy Christian \& Eymard-Duvernay François (eds.) (1997). Les Intermédiaires du marché du travail. Paris, Presses universitaires de France.

Bessy Christian \& Chauvin Pierre-Marie (2013). "The Power of Market Intermediaries: From Information to Valuation Processes." Valuation studies, 1(1): 83-117.

Bessy Christian \& Chauvin Pierre-Marie (2014). "Intermédiaires de marché." In Grossetti Michel, Zalio Pierre-Paul, Chauvin Pierre-Marie (eds.), Dictionnaire sociologique de l'entrepreneuriat. Paris, Les Presses de Sciences Po: 361-379.

Bielby Denise \& Bielby William T. (1993). "The Hollywood 'Graylist'? Audience Demographics and Age Stratification among Television Writers." In Cantor M.G. \& Zollars C. L. (eds.), Current Research in Occupations and Professions. Greenwich, JAI Press, vol. 8: 141-172.

Bielby Denise D. \& BIElby William T. (1999). "Organizational Mediation of Project-Based Labor Markets: Talent Agencies and the Careers of Screenwriters." American Sociological Review, 64(1): 64-85.

BOURDIEU Pierre (1984). Distinction. A Social Critique of the Judgement of Taste. Translated by Richard Nice. Cambridge, Harvard University Press: 133-168

Boussard Valérie, Demazière Didier, Milburn Philip (eds.) (2010). L'Injonction au professionnalisme. Analyses d'une dynamique plurielle. Rennes, Presses universitaires de Rennes.

Brigaud-Robert Nicolas (2011). Les Producteurs de télévision. Socioéconomie d'une profession. Saint-Denis, Presses universitaires de Vincennes. 
CARDON Vincent (2016). « Produire “l'évidence”. Le travail d'appariement et de recrutement dans le monde du cinéma ". Sociologie du Travail, 58(2) : 160-180.

CARDON Vincent \& PILmIS Olivier (2013). « Des projets à la carrière. Les artistes interprètes et leurs anticipations des contreparties du travail, une perspective biographique ». Sociétés contemporaines, 91: 43-65.

Chalvon-Demersay Sabine \& Pasquier Dominique (1993). "Les mines de sel : auteurs et scénaristes de télévision ». Sociologie du travail, 35(4) 409-413.

Chalvon-Demersay Sabine (2011). " Enquête sur l'étrange nature du héros de série télévisée ». Réseaux, 165 : 181-214.

Collectif (2018). Noire n'est pas mon métier. Paris, Seuil.

Donnat Olivier (2009). Les Pratiques culturelles à l'ère numérique. Paris, La Découverte.

EsquenaZl Jean-Pierre (2010). Les Séries télévisées : l'avenir du cinéma ?. Paris, Armand Colin.

GlévareC Hervé (2005). «La fin du modèle classique de la légitimité culturelle. Hétérogénéisation des ordres de légitimité et régime contemporain de justice culturelle. L'exemple du champ musical ». In MalgRET Éric \& MACÉ Éric (dir.), Penser les médiacultures. Nouvelles pratiques et nouvelles approches de la représentation du monde. Paris, INA-Armand Colin : 69-102.

GLÉVAREC Hervé (2012). La Sériephilie. Sociologie d'un attachement culturel et place de la fiction dans la vie des jeunes adultes. Paris, Ellipses.

GréGoIRE Mathieu (2013). Les Intermittents du spectacle : enjeux d'un siècle de luttes. Paris, La Dispute.

KARPIK Lucien (2007). L'Économie des singularités. Paris : Gallimard.

KARPIK Lucien (2011). Valuing the Unique. The Economics of Singularities. Traduit en anglais par Nora Scott. Princeton, Princeton University Press.
CARDON Vincent (2016). "Produire 'l'évidence'. Le travail d'appariement et de recrutement dans le monde du cinéma." Sociologie du Travail, 58(2): 160-180.

CARDON Vincent \& PILmis Olivier (2013). "Des projets à la carrière. Les artistes interprètes et leurs anticipations des contreparties du travail, une perspective biographique." Sociétés contemporaines, 91: 43-65.

Chalvon-Demersay Sabine \& Pasquier Dominique (1993). "Les mines de sel: auteurs et scénaristes de télévision." Sociologie du travail, 35(4): 409-413.

Chalvon-Demersay Sabine (2011). "Enquête sur l'étrange nature du héros de série télévisée." Réseaux, 165: 181-214.

Collectif (2018). Noire n'est pas mon métier. Paris, Seuil.

Donnat Olivier (2009). Les Pratiques culturelles à l'ère numérique. Paris, La Découverte.

EsquenazI Jean-Pierre (2010). Les Séries télévisées : l'avenir du cinéma?. Paris, Armand Colin.

GLÉVAREC Hervé (2005). "La fin du modèle classique de la légitimité culturelle. Hétérogénéisation des ordres de légitimité et régime contemporain de justice culturelle. L'exemple du champ musical." In MaIGRet Éric \& Macé Éric (eds.), Penser les médiacultures. Nouvelles pratiques et nouvelles approches de la représentation du monde. Paris, INA/Armand Colin: 69-102.

GLÉVAREC Hervé (2012). La Sériephilie. Sociologie d'un attachement culturel et place de la fiction dans la vie des jeunes adultes. Paris, Ellipses.

GRÉGOIRE Mathieu (2013). Les Intermittents du spectacle: enjeux d'un siècle de luttes. Paris, La Dispute.

KARPIK Lucien (2007). L'Économie des singularités. Paris, Gallimard.

KARPIK Lucien (2011). Valuing the Unique. The Economics of Singularities. Traduit en anglais par Nora Scott. Princeton, Princeton University Press. 
KaTz Serge (2015). Comédiens par intermittence. Le métier à l'épreuve de la disqualification professionnelle. Paris, Presses du Châtelet.

LE GUERN Philippe (2006). « Monter les séries : une activité sous contrainte ». Médiamorphoses, 3 : 35-39.

LizÉ Wenceslas, NaUdier Delphine, Roueff Olivier (2011). Intermédiaires du travail artistique : à la frontière de l'art et du commerce. Paris, DEPS/ La Documentation française.

LizÉ Wenceslas, NaUdieR Delphine, SofiO Séverine (dir.) (2014). Les Stratèges de la notoriété. Intermédiaires et consécration dans les univers artistiques. Paris, Archives contemporaines.

McCABE Janet \& AKASS Kim (2007). Quality Television : Contemporary American Television and Beyond. Londres, I.B. Tauris.

Menger Pierre-Michel (1997a). La Profession de comédien. Formations, activités et carrières dans la démultiplication de soi. Paris, Ministère de la Culture et de la Communication/La Documentation française.

Menger Pierre-Michel (1997b). « L'activité du comédien. Liens, indépendances et microorganisations ». Réseaux, $86:$ 59-75.

Menger Pierre-Michel (2005). « Liens, interdépendances et microorganisations dans le système d'activité des comédiens ». In CRETON Laurent, Palmer Michael, SarRazac Jean-Pierre (dir.), Arts du spectacle, métiers et industries culturelles : penser la généalogie. Paris, Presses Sorbonne Nouvelle : 103-124.

Menger Pierre-Michel (2009). Le Travail créateur. S'accomplir dans l'incertain. Paris, Gallimard/Seuil.

Menger Pierre-Michel (2011). Les Intermittents du spectacle. Sociologie du travail flexible. Paris, EHESS.

Mille Muriel (2013). Produire de la fiction à la chaîne : sociologie du travail de fabrication d'un feuilleton télévisé, Thèse de doctorat en sociologie. Paris, EHESS

MiLle Muriel (2016). « Le processus collectif de création d'un feuilleton télévisé », Sociétés contemporaines, $101: 91-114$.
Katz Serge (2015). Comédiens par intermittence. Le métier à l'épreuve de la disqualification professionnelle. Paris, Presses du Châtelet.

LE GUERN Philippe (2006). "Monter les séries: une activité sous contrainte." Médiamorphoses, 3: 35-39.

Lizé Wenceslas, NAUdier Delphine, Roueff Olivier (2011). Intermédiaires du travail artistique : à la frontière de l'art et du commerce. Paris, DEPS/ La Documentation française.

LizÉ Wenceslas, NAUdiER Delphine, Sofio Séverine (eds.) (2014). Les Stratèges de la notoriété. Intermédiaires et consécration dans les univers artistiques. Paris, Archives contemporaines.

McCABE Janet \& AKASs Kim (2007). Quality Television: Contemporary American Television and Beyond. Londres, I.B. Tauris.

Menger Pierre-Michel (1997a). La Profession de comédien. Formations, activités et carrières dans la démultiplication de soi. Paris, Ministère de la Culture et de la Communication/La Documentation française.

Menger Pierre-Michel (1997b). "L'activité du comédien. Liens, indépendances et microorganisations." Réseaux, 86: 59-75.

Menger Pierre-Michel (2005). "Liens, interdépendances et microorganisations dans le système d'activité des comédiens." In CRETON Laurent, PALmer Michael, SARRAZAC Jean-Pierre (eds.), Arts du spectacle, métiers et industries culturelles: penser la généalogie. Paris, Presses Sorbonne Nouvelle: 103-124.

Menger Pierre-Michel (2011). Les Intermittents du spectacle. Sociologie du travail flexible. Paris, EHESS.

Menger Pierre-Michel (2012). The Economics of Creativity. Art and Achievement Under Uncertainty. Translated in English by Steven Rendall, Amy Jacobs, Arianne Dorval, Lisette Eskinazi. Cambridge, Harvard University Press.

MiLle Muriel (2013). Produire de la fiction à la chaîne: sociologie du travail de fabrication d'un feuilleton télévisé, Ph.D. Thesis, Sociology. Paris, EHESS. 
NAUDIER Delphine \& ROUEFF Olivier (2013). « Le monde clivé des agents de talents ». In Rot Gwenaelle, Verdalle Laure (de) (dir.), Le Cinéma. Travail et organisation. Paris, La Dispute : 129-146.

NAUDIER Delphine (2014). «Les agents artistiques du cinéma français : des intermédiaires (in)visibles ». In JEANPIERRE Laurent \& ROUEFF Olivier (dir.), La Culture et ses intermédiaires. Dans les arts, le numérique et les industries créatives. Paris, Éditions des archives contemporaines : 113124.

Naudier Delphine (2015). «The Talent Agent's Role in Producing Artists Symbolic and Commercial Value in France ». In BIELBY Denise \& RousSEL Violaine (dir.), Brokerage and Production in the American and French Entertainment Industries : Invisible Hands in Cultural Markets. New York, Lexington Books : 55-74.

NAUDIER Delphine (2018a). Des alchimistes de la valeur. Sociologie historique des agents artistiques. Habilitation à diriger des recherches. Strasbourg, Université de Strasbourg.

NAUDIER Delphine (2018b). " "Faire le nom" des artistes en construisan un "monopole de singularité" ». In BERGER Marianne, MAYER Ariane, OUdART Pierre, THIAULT Jennifer (dir.), Ni vu ni connu. La notoriété des artistes au défi de l'économie numérique. Actes des journées d'étude. Paris, Ministère de la Culture/Direction générale de la création artistique : 63-72.

PASQUIER Dominique (1995). Les Scénaristes et la télévision : approche sociologique. Paris, INA.

PASQUIER Dominique (2008). « Conflits professionnels et luttes pour la visibilité à la télévision française ». Ethnologie française, 38(1).

PILMIS Olivier (2008). « L'organisation de marchés incertains : sociologie économique des mondes de la pige et de l'art dramatique ». Thèse de doctorat en sociologie. Paris, EHESS.

PILMIS Olivier (2013). L'Intermittence au travail. Une sociologie des marchés de la pige et de l'art dramatique. Paris, Economica.
MiLle Muriel (2016). "Le processus collectif de création d'un feuilleton télévisé », Sociétés contemporaines, 101: 91-114.

NAUDIER Delphine \& RouefF Olivier (2013). "Le monde clivé des agents de talents." In Rot Gwenaelle, Verdalle Laure (de) (eds.), Le Cinéma. Travail et organisation. Paris, La Dispute: 129-146.

NAUDIER Delphine (2014). "Les agents artistiques du cinéma français: des intermédiaires (in)visibles." In JEANPIERRE Laurent \& ROUEFF Olivier (eds.), La Culture et ses intermédiaires. Dans les arts, le numérique et les industries créatives. Paris, Éditions des archives contemporaines: 113124.

NAUDIER Delphine (2015). "The Talent Agent's Role in Producing Artists' Symbolic and Commercial Value in France." In BIELBY Denise \& RousseL Violaine (eds.), Brokerage and Production in the American and French Entertainment Industries: Invisible Hands in Cultural Markets. New York Lexington Books: 55-74.

NAUDIER Delphine (2018a). Des alchimistes de la valeur. Sociologie historique des agents artistiques. Habilitation à diriger des recherches. Strasbourg, Université de Strasbourg.

NAUDIER Delphine (2018b). “'Faire le nom' des artistes en construisant un 'monopole de singularité'." In BERGER Marianne, MAYER Ariane, OUdART Pierre, ThIAULT Jennifer (eds.), Ni vu ni connu. La notoriété des artistes au défi de l'économie numérique. Actes des journées d'étude. Paris, Ministère de la Culture/Direction générale de la création artistique: 63-72.

PASQUIER Dominique (1995). Les Scénaristes et la télévision: approche sociologique. Paris, INA.

PASQUIER Dominique (2008). "Conflits professionnels et luttes pour la visibilité à la télévision française." Ethnologie française, 38(1).

PILMIS Olivier (2008). "L'organisation de marchés incertains: sociologie économique des mondes de la pige et de l'art dramatique." Ph.D. Thesis, Sociology. Paris, EHESS. 
RousseL Violaine (2017). Representing Talent. Hollywood Agents and the Making of Movies. Chicago, The University of Chicago Press.

SINIGAGLIA Jérémy (2017). «La consécration qui ne vient pas. Réduction. ajustement et conversion des aspirations des artistes ordinaires du spectacle ». Biens symboliques/Symbolics Goods, 1. En ligne.

ZaFIRAU Stephen (2008). « Reputation Work in Selling Film and Television: Life in the Hollywood Talent Industry ». Qualitative Sociology, 31(2) : 99127.
PILMIS Olivier (2013). L'Intermittence au travail. Une sociologie des marchés de la pige et de l'art dramatique. Paris, Economica.

Roussel Violaine (2017). Representing Talent. Hollywood Agents and the Making of Movies. Chicago, The University of Chicago Press.

SINIGAGLIA Jérémy (2017). "A Consecration that Never Comes. Reduction. Adjustment and Conversion of Aspirations among Ordinary Performing Artists." Translated in English by Jean-Yves Bart. Biens symboliques/ Symbolic Goods, 1. Online.

ZafiRAU Stephen (2008). "Reputation Work in Selling Film and Television: Life in the Hollywood Talent Industry." Qualitative Sociology, 31(2): 99127. 